日消外会誌 $14(5): 645 \sim 652,1981$ 年

\title{
食道粘膜下造影像と手術成績
}

\author{
福島県立医科大学第 1 外科（指導：本多憲児教授） \\ 鈴一木謙

\section{THE ESOPHAGEAL SUBMUCOGRAPHY AND SURGICAL RESULTS OF ESOPHAGEAL CARCINOMA}

\section{Yuzuru SUZUKI}

First Department of Surgery, Fukushima Medical School

(Director : Prof. Kenji Honda)

\begin{abstract}
食道癌の53例に食道粘膜下造影法を行い，その手術成績との関連について検討した。粘膜下像第 I 型 （19例）では切除率73\%，深達度は全て $a_{3}$ で術後成績も不良であった．第而（13例）を示した症例は 切除率 $92 \%$ (非切除は手術拒否による) で，深達度 $a_{0} ， a_{1}$ て術後成績も良好であった。第正型 (21例) を示した症例は切除率 $90 \%$, 深達度 $\mathrm{a}_{2}$ のあのがほとんどで，手術成績も正型に次いで良好であった。手 術成績よりみると II 型は合併療法なしにも長期生存を期待し得るが，Ｉ，而型症例では長期生存を期待す るためには合併療法が不可欠のものと考えられた。
\end{abstract}

索引用語 : 食道癌, 食道粘膜下造影法, 食道粘膜下像, 食道癌術後成繢, 食道癌合併療法

食道癌手術は年々增加の一途をたどっているが，手術 前に癌の浸潤の程度を知ることは手術成績向上のために は極めて重要である. 癌の外膜浸潤”を術前に知る方法 としては食道軸の変位 ${ }^{2)}$, 気管偏位の検討 ${ }^{3)}$, 綎隔鏡(等 が行われているが未だ適確な猃断をすることは困難であ った. 教室では, 癌外膜浸潤の程度を術前に無血的に 判定する目的をむって食道粘膜下造影法 ${ }^{576)}$ を施行, 食 道粘膜下造影像の意義㧍よび食道粘膜下像と組織所見に ついて報告 ${ }^{778)}$ ，食道粘膜下造影の有用性について報告 した. 著者は教室に入院中，手術せる食道癌201例のう ち, 最近の53例飞食道粘膜下造影法を行い, 食道粘膜下 像と手術成績との関連を検索したので, その成績をのべ る.

\section{症例}

症例は昭和 50 年 5 月より 55 年 9 月までに食道粘膜下造 影法を行った食道癌53例で，このうら45例 (85\%) は切 除，8例（15\%) は非切除であった. 手術を行わなかっ た 8 例は気管支瘦 3 例, 心不全, 遠隔転移, 喉頭癌合 併, 高齢 (84歳), 手術拒否各 1 例であった。

食道粘膜下造影法は教室千葉らの方法 ${ }^{7}$ に従った。
た食道粘膜下像の分類は千葉ら”従い，粘膜下に注入 せる造影剤が腫港上㟤で完全に途絶を示す第 I 型, 畽瘍 外側に流入し, 腫場の肛門側に達する第 II 型, 腫湯上緑 より一部腫掦外側に流入するが肛門側までは達しない第 III型に分類した（図1).

\section{I. 食道粘膜下像各型症例}

食道粘膜下造影法を行った53例の食道粘膜下像（以 下粘膜下像 と略す） は第 I 型19例（35\%），第 II 型13例 (25\%)，第正型21例（40\%）であった。

第 I 型19例（表 1) は48 84歳, 平均65.3歳, 男16 例, 女 3 例, 部位別には Ce 2 例, Iu 2 例, Im 13例, Ei 2 例であった. このらち14例 (73\%) は切除，5例 （27\%）は切除不能であった。切除不能 5 例のうち 3 例 (No. 7732 ，No. 8304 , No. 8307) 忙気管支瘦形成, 1 例 (No. 7987) は84藏の高龄, 1 例 (No. 8025) は頭蓋 骨等への骨転移の認められた症例であった。切除14例の 手術々式は 6 例では胸骨後食道胃吻合術, 3 例では胸骨 前食道胃吻合, 3 例では後綎隔咽頭胃吻合, 2 例では右 胸腔内食道胃吻合術であった。 
表 3 第 III 型症例

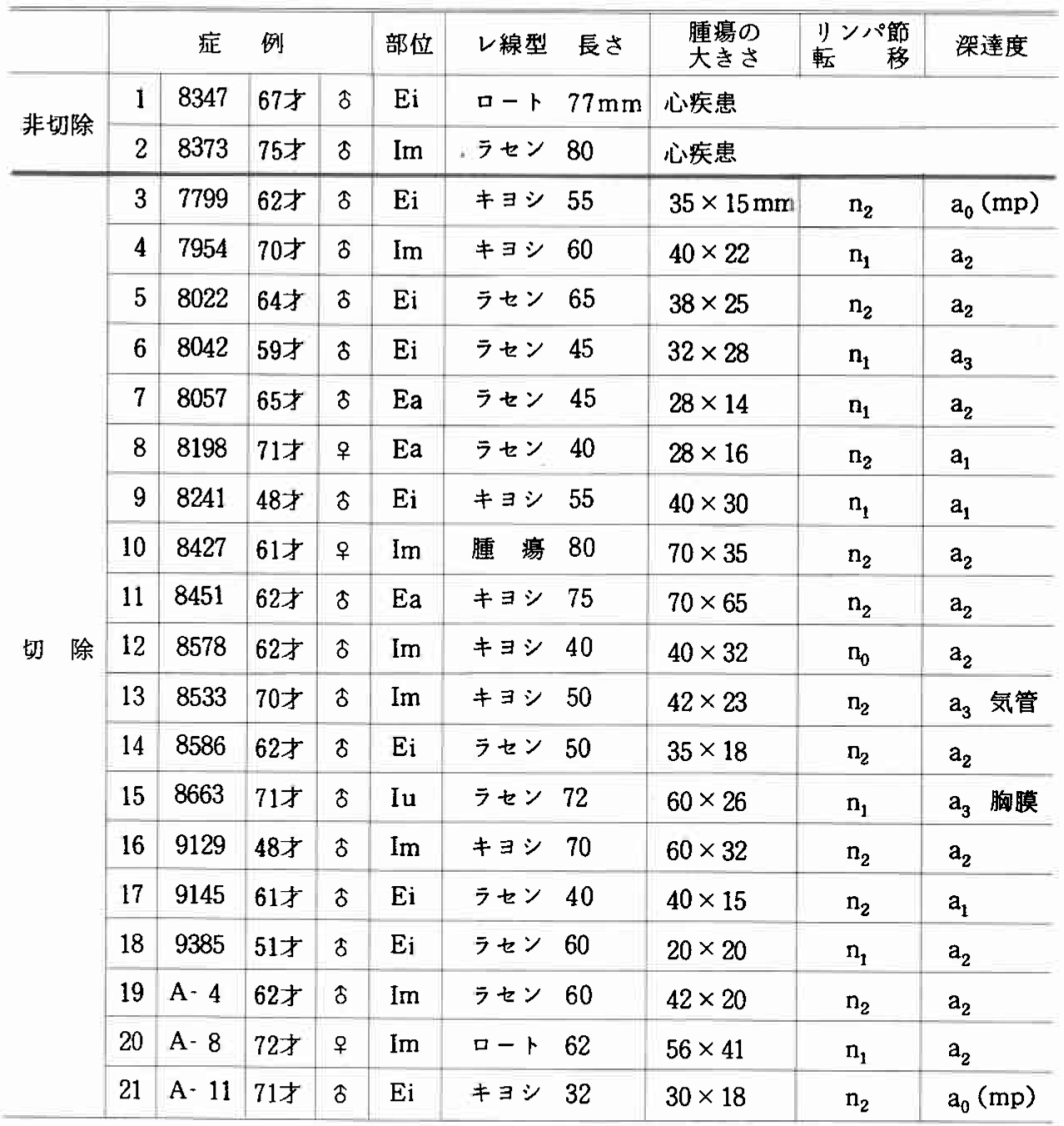

$42.4 \mathrm{~mm}$, 横径 $15 \sim 65 \mathrm{~mm}$, 平均 $26.6 \mathrm{~mm}$ で癌浸潤は一部 外膜に達する $\mathrm{A}_{1} \sim \mathrm{A}_{2}$ の所見であった. これらのリンパ 節転移は $\mathrm{n}_{0} 1$ 例, $\mathrm{n}_{1} 7$ 例, $\mathrm{n}_{2}$ 11例であった。

\section{III. 粘膜下像と摘出標本組幽所見}

第 I 型14例の組織型は高分化型 4 例，中分化型 4 例, 低分化型 6 例で，いずれも深達度は外膜を貫く浸潤のみ られる $a_{3}$ であった。

第 II 型12例では高分化型 5 例，中分化型 4 例，低分化 型 3 例で浸潤は筋層までにとどまる $a_{0}$ が 9 例で， 3 例 ではわずかに外膜に達する $a_{1}$ であった。

第 III型19例では高分化型 7 例, 中分化型 8 例, 低分化 型 4 例で，外膜に漫潤のない $a_{0} 2$ 例，浸潤のみられる $a_{1} 3$ 例， $a_{2} 12$ 例，外膜を超える浸潤のみられる $a_{2} 2$ 例であった。

これら45例における a 因子と粘膜下像との関連を表 4 に示す， $a_{0} 11$ 例では II型 9 例 (82\%) 林型 2 例 (18
表 4 粘膜下像と深達度

\begin{tabular}{c|c|l|l|l|l}
\hline \hline & $a_{0}$ & \multicolumn{1}{|c|}{$a_{1}$} & $a_{2}$ & $a_{3}$ & 計 \\
\hline I 型 & 0 & 0 & 0 & $14(100)$ & 14 \\
\hline II 型 & $9(75)$ & $3(25)$ & 0 & 0 & 12 \\
\hline III 型 & $2(9)$ & $3(14.5)$ & $2(62)$ & $2(9.5)$ & 19 \\
\hline & 11 & 6 & 12 & 16 & 45
\end{tabular}

\%)でI型なく， $a_{1} 6$ 例ではII型，且型とれぞれ 3 例 でI型はみられなかった： $a_{2}$ の12例は全例型であっ た. $a_{3}$ 16例は14例 (87.5\%) はI型，2例 (12.5\%) が而型でII 型はみられなかった。

すなわち $a_{3}$ の大部分が I 型, $a_{0}, a_{1}$ の大部分が II 型 又は正型で， $a_{2}$ は全例正型であった。

IV. 粘䐵下像と手術成繈

粘膜下像と手術成績についてのべる. 
図 3 症例 No. 8373の粘膜下造影像 第 III 型

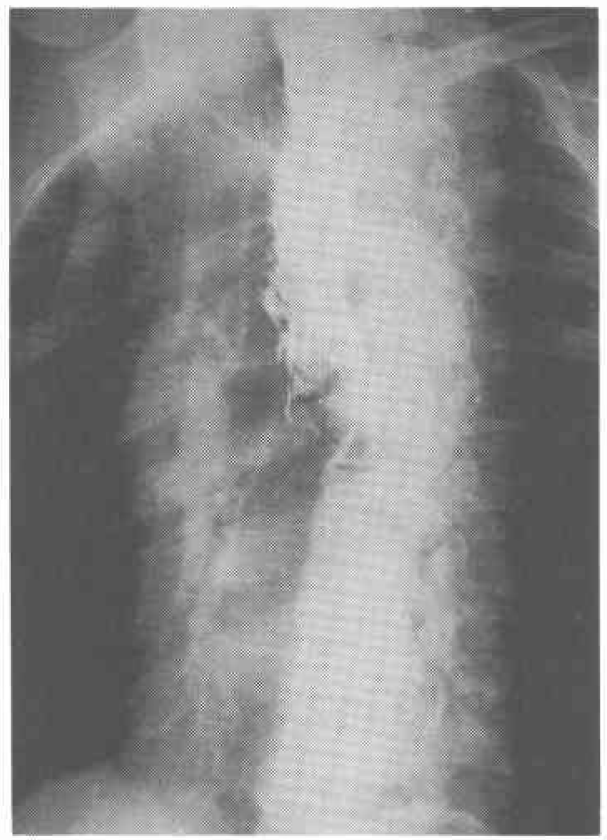

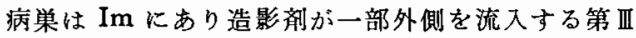
型を示した。

図 5 症例 No. 8347 の心電図

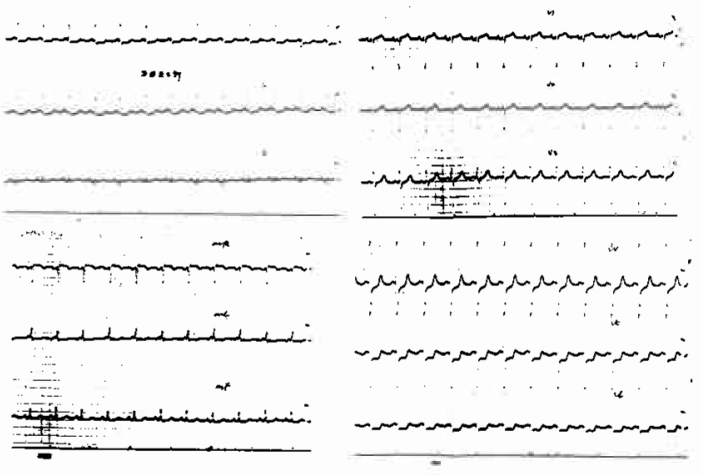

\section{1) 第 I 型症例}

第 I 型症例の手術成績を表 5 に示す. 4 例は腷出血, 心筋硬塞等により術後 $1 \sim 5$ 力月間に死亡した他病死で ある.

8 例は再発死であるが，この5ち 7 例は 1 年以内に再 発を見，1例 (No. 8156) は 2 年後に再発死亡した。 こ の 1 例は73歳, 男, Im で気管支への浸潤の認められた
図 4 症例 No. 8347 の粘膜下造影像

第四型

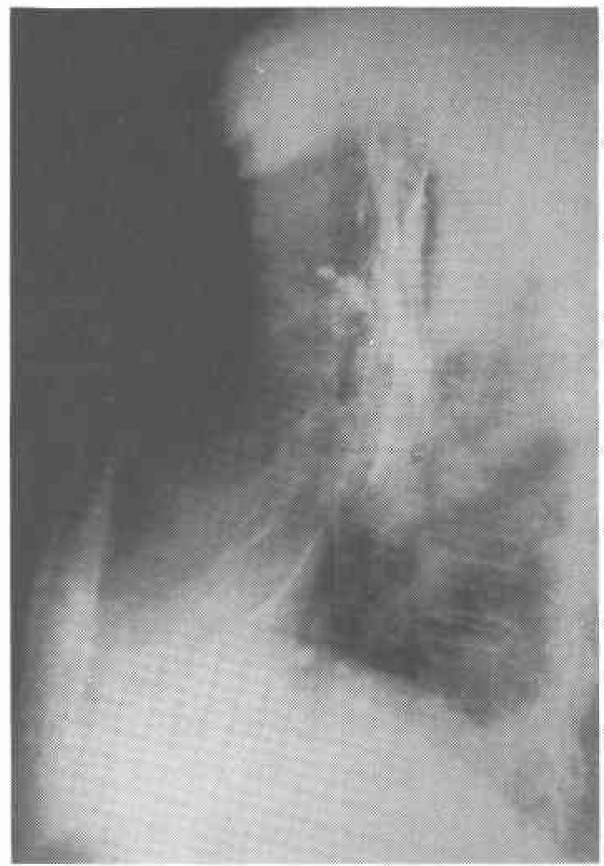

病巣は Ei にあり造影剂が一部外側を流入する第正 型を示した。

図 6 症例 No. 8118 の組織像

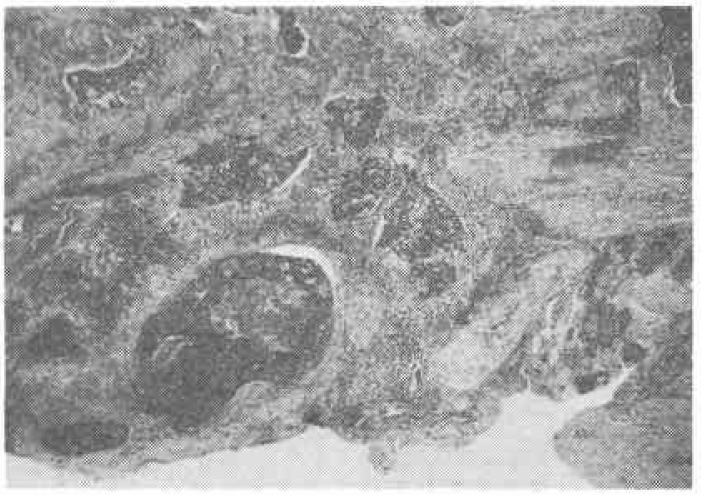

外膜を貫く浸潤のみられた $\mathrm{a}_{3}$ であった。

$a_{3}$ 症例で， $n_{1}$ (No. 108甲) であった，胸骨後食道胃吻 合術を施行し, 3000r の術後照射を行い，その後通常の 日常生活を送っていたが，術後 2 年咳嗽，胸水貯溜をみ る後綖隔再発により死亡した.

2 例は現在生存中であるが，1 例 (No.A-10) は現在 
表 5 第 I 型症例の手術成績

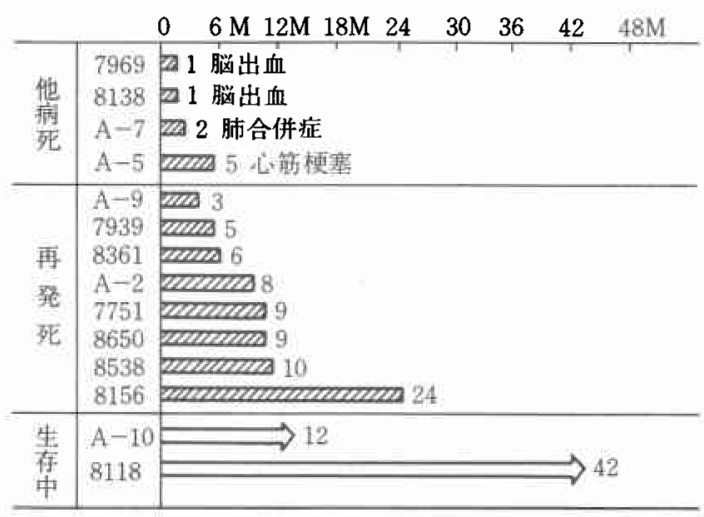

術後 1 年で術後日浅いが，他の 1 例 (No. 8118) は術後 3 年 6 力月を経過 した現在生存中である. 本症例は68 歳男, Im で壆腫表面の右壁側肋膜への浸潤が認められ

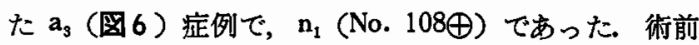
BLM $80 \mathrm{mg} ， 2000 \mathrm{r}$ の術前処理後に胸腔内食道胃吻合術 を行い，さらに術後4000r の照射を行って 3 年 6 力月生 存中である.

\section{2）第 II 型症例}

第 II 型症例の手術成績を表 6 に示す. 2 例は他病死で ある. 1 例は術後 2 力月肺炎により，1 例は術後11力月 イレウスにより死亡した. いずれも術後管理不充分のた めと考えられた。

再発例は 2 例で 1 例 (A-1) は16力月, 1 例 (No. 7928) は 2 年10カ月後に死亡した. No. A-1 は52歳男, Im で胸 骨後食道胃吻合術を行った。 $a_{0}(\mathrm{mp})$ （図 7)， $\mathrm{n}_{1}$ (No. $106,107 \oplus)$ で ly (十), v (十) であった. 術後 1 年 4 カ月脳転移のために死亡した. No. 7928は52歳男, Im

表 6 第 II 型症例の手術成績

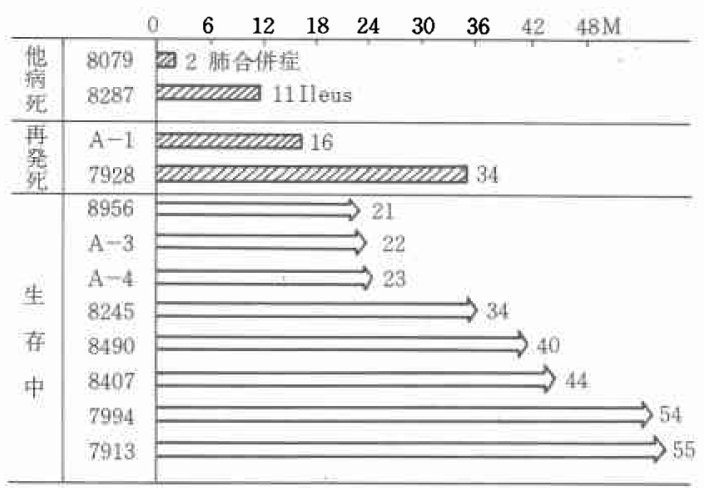

図 7 症例 A-1 の組像

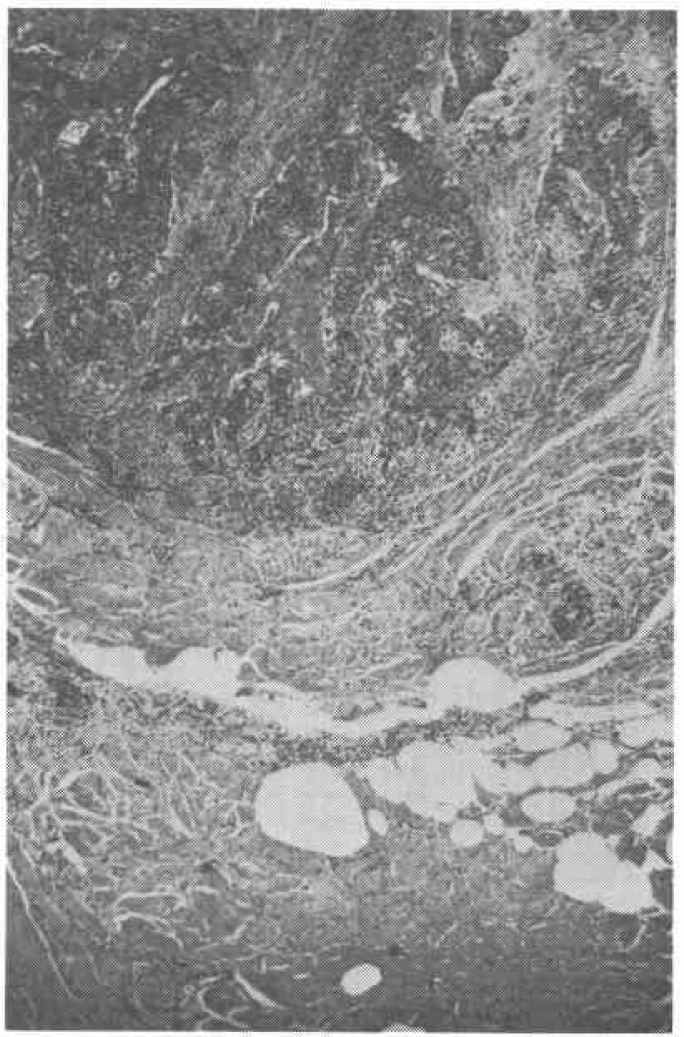

深達度は $a_{0}(\mathrm{mp})$ であった。

胸骨後食道胃吻合術を行った症例で，sm， $n_{0}, l y(-)$, v（一，であったが術後 2 年10カ月䫓部リンパ節転移 を来たし死亡した．本症例には䅡部りンパ節廍清は行わ れて扣らずまな再発せる 2 例にはいずれる術前後の合 併療法は施行されていなかった。

他の 8 例は現在生存中であり，3 例は未だ術後 2 年以 内であるが，他の 5 例は 2 年以上経過し，最近 4 年 6 カ月の現在健康である. 4 年以上生存の 2 例のちち No. 7994は65歳男， Ei で胸暌内食道胃吻合術を行った症例 で $\mathrm{a}_{1}, \mathrm{n}_{2}$ (No. $110,112 \oplus$ ), ly (†), v (-) であった. 現在 4 年 6 力月健康である. No. 7913は65歳女, Im で 胸究前食道胃吻合術を行った症例で $a_{1}, n_{0}, l y(-), v$ （一）であった，術後 4 年 6 力月健康である. いずれの 症例にも術後合併療法は施行されていない。

3) 第 III 型症例

第正型症例の手術成績を表 7 に示す. 5 例は術後合併 症による他病死であった。 
表 7 第型症例の手術成績

\begin{tabular}{|c|c|c|}
\hline & & $\begin{array}{lll}30 & 36 & 42\end{array}$ \\
\hline $\begin{array}{l}\text { 能 } \\
\text { 病 } \\
\text { 死 }\end{array}$ & $\begin{array}{l}7799 \\
7954 \\
8022 \\
8241 \\
A-8\end{array}$ & 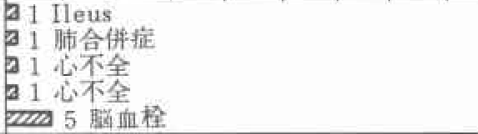 \\
\hline $\begin{array}{l}\text { 再 } \\
\text { 㩆 }\end{array}$ & $\begin{array}{l}\text { A-4 } \\
8663 \\
8451 \\
9129 \\
8578 \\
8533 \\
8198 \\
8042\end{array}$ & 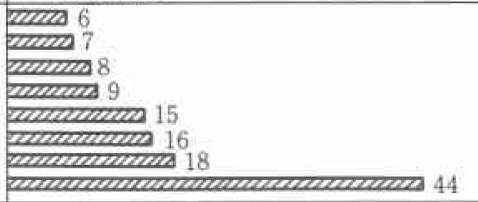 \\
\hline $\begin{array}{l}\frac{4}{\text { 曹 }} \\
\text { 中 }\end{array}$ & $\begin{array}{l}9385 \\
A-11 \\
9145 \\
8057 \\
8586 \\
8427\end{array}$ & 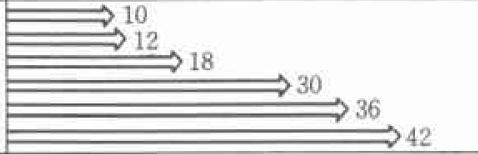 \\
\hline
\end{tabular}

再発死亡は 8 例で，そのうち 7 例は 1 年 6 カ月以内に 死亡， 1 例 (No. 8042) は術後 3 年 8 カ月再発死亡し た. No. 8042は59歳男, Ei で術前 BLM 150mg 投与後 に胸腔内食道胃吻合術を行った。 $a_{2}, n_{1}$ (No. $110 \oplus$ ), ly (十), v (-) であった. 術後 3000r の照射を行い 術後経過良好であったが，癌性腹膜炎のためかと思われ る腹水が出現し, 術後 3 年 8 カ月に死亡した症例であっ た.

他の 6 例は現在生存中である. 4 例は未だ 2 年以内で あるが，他の 2 例は 3 年， 3 年 6 力月の現在生存中であ る. No. 8586は62歳男 Ei で胸腔内食道胃吻合術を行っ た $\mathrm{a}_{0}, \mathrm{n}_{2}$ (No. 110,111, 1, 2, $\oplus$ ) ly (+), v (-) 症例で, 術後 3 年通常の生活を送っている. No. 8427 は 61歳女, Im で胸骨後食道胃吻合術を行った $\mathrm{a}_{2}, \mathrm{n}_{2}$ (No. $107,110,1 \oplus), 1 y(-), v(-)$ 症例で術後 3 年 6 力 月現在家事に従事中である.これら長期生存中の 2 例に はいずれもそれぞれ術前 BLM $65 \mathrm{mg}, 45 \mathrm{mg}$ 術後4000r, 3200r の術後照射の合併療法が施行されている.

\section{考 察}

食道粘膜下造影法は和田 ( $^{5)}$, 斎藤ら ${ }^{6}$ とより始めら れ，食道癌の深達度の判定に有用である之報告した。教 室では粘膜下造影像を 3 型に分類し千葉ら 子粘膜下造影像之深達度との関保について報告した。著 者の切除45例についてみると， $a_{3}$ 16例中14例， $87.5 \%$ が I 型を示し， $a_{2}$ は田型， $a_{1}$ はII型又は形， $a_{0}$ では $82 \%$ が II 型, $18 \%$ が II 型であり，粘膜下造影像と深達度 には深い関連が認められた。

第 I 型，第 I 型，第 II 型各型の手術成績についてみる に他病死例は I 型 4 例 $(29 \%)$ ， II 型 2 例 $(17 \%)$ ， II 型
5 例 $(26 \%)$ で II 型でやや少なく， I ， II 型は大よそ 同様にみられた。 このことはII 型は比較的早期のもので あり，I， II型は進行性のもので全身状態の不良のるの が多い為と考兄られた．また死因としては肺炎（3例）， 脳出血 ( 3 例), 心筋硬塞 ( 3 例), イレウス ( 2 例) が 多くみられた。磯野”，渡辺ら ${ }^{10}$ 快肺资が多かったとの べているが，著者例では脳出血，心筋硬塞，イレウスが 多くみられ，最近の呼吸管理の向上により肺炎の死亡が 減じ，その他による死亡が増加したものと思われた。

食道癌手術の手術成績を左右するるのは再発死である が，諸家報告8)11112３) によれば食道癌手術後再発死亡は 1 年以内 $40 \sim 60 \%, 2$ 年60 75\%, 3 年70 $80 \%, 4$ 年 $75 \sim 85 \% ， 5$ 年80 90\%とされている. 著者症例では術 後10カ月〜 5 年の観察期間であるが第 I 型全体で57\%， 第 II 型 $17 \%$ ，第正型 $42 \%$ で第 I 型は高頻度であったが 第 II 型では極めて少数であった. しかし第 I 型症例中 2 例のみであるが再発がみられた。このらち ly $(+), \mathrm{v}$ $(+) の 1$ 例が 1 年 4 力月後に脳転移, ly ( $(-), v(-)$, $\mathrm{n}_{\mathrm{o}}$ の 1 例は 2 年10カ月右頝部リン八節転移により死亡 した.これら 2 例では合併療法を行わなかったが, No. A-1 では化学㞠法を, No. 7928では葛西 ${ }^{13)}$, 渡辺ら ${ }^{14)}$ いら如く頚部を含めた $\mathrm{T}$ 字型術後照射を行らべきであっ たと反省している.

I 型の再発率57\%は I 型を示した症例の手術適応の限 界を示するのであり，合併療法との併用を考慮しなけれ ばならない。このことは I 型において 2 年後に再発した 1 例は $a_{3}, n_{1}$ であったものであるが，本症例では術後放 射線療法を行ったものであることにより肯定される. III 型再発は $42 \%$ で半数以下であり，血型を示したものは一 応根治手術を試みるべきである。このうち 7 例は 1 年 6 カ月以内に死亡したが， 1 例は $\mathrm{a}_{2}, \mathrm{n}_{1}, \mathrm{ly}(+), \mathrm{v}(-)$ であったにもかかわらず 3 年 8 カ月生存した，本症例で は術前飞 BLM, 術後飞放射線療法が行われていた。 こ のことよりみれば第正型であれば合併療法を行えば充分

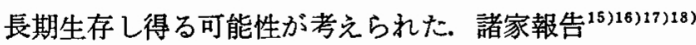
に上れば $\mathrm{a}_{2}$ 症例は 5 年生存率は15 25\%とされている ことよりみれば 3 年 8 カ月生存は比較的長期生存し得た と考觉られた。

現在生存中の症例については第 I 型 14例中 2 例 (14 \%)で，1例は未だ術後 1 年， 1 例は術後 3 年 6 力月を 経過している. 3 年 6 力月経過の 1 例は $\mathrm{a}_{3}, \mathrm{n}_{2}, \mathrm{ly}(-)$, v (一) で術前, 術後に BLM, 放射線合併療法を行っ た. 第 II 型12例では 8 例（67\%）生存，このうち 3 例は 
未だ術後 2 年以内であるが， 5 例は 2 年以上経過し，こ のちち 2 例は 4 年以上経過し，しかもこの 2 例は合併療 法を行わなかった。

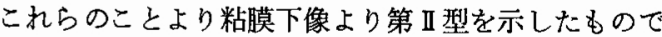
は合併療法を行わなくとも長期生存例を得ることがでさ るが第 I， III型では合併療法を行えば長期生存の可能 性のあることを示したものと考兄られ，粘膜下造影法は 手術成續向上の為にも有意義な術前診断手技之考えられ た.

\section{結語}

食道粘膜下造影法を食道癌 53 例に施行, うち45例に手 術を行い手術成績を検討し，次の結論を得た.

1）粘莫下像第 I 型19例では切除14例（切除率73\%） で，その深達度は全て $a_{3}$ であった。 また手術施行14例 のうち $57 \% か ゙$ 再発により短期間に死亡した。

2）粘莫下像第 II 型13例では切除12例（切除率 $92 \%$ ) で, 深達度は $a_{0} 9$ 例， $a_{1} 3$ 例であった. 再発死亡は 2 例（17\%）のみであった。

3）粘膜下像第 II 型21例では切除19例（切除率90\%) で，深達度は $a_{0} 2$ 例， $a_{1} 3$ 例， $a_{2}$ 12例， $a_{3} 2$ 例であ った. 再発死亡は 8 例 $(42 \%)$ であった.

4）粘膜下像第 I・III型症例での長期生存例はいずれ 子合併療法施行例であった。

5）食道粘膜下造影法は術前に食道癌の外膜浸润程度 の判定及び予後の推定に有用であり，食道癌の治療方針 決定に極めて有意義であると考えられた。

稿を終るに臨み，ご指導，ご校閱を賜った恩師本多憲 児教授に深甚なる謝意を捧げるとともに，直接ご指導を 載いた元木良一助教授，千葉 惊助教授，坪井正碩諥師 に感謝の意を表する。

\section{文 献}

1）食道疾患研究会：食道癌取扱い規約，金原出
版, 東京, 1974 .

2) 秋山洋, 木暮 喬：食道癌の手術適応とX線 上の食道軸について。外科, $32 ： 673-683$, 1970.

3) 颚谷一諴他：胸部食道癌病巣診断に怙ける気管 分岐部呼吸性移動距離測定について，日消外会 誌, 7:637-643, 1974 .

4) 高橋啓泰他：綎隔鏡における A-factor の直視 下の検索。日消外会誌, $9: 243-249,1976$.

5）和田寞治他：食道粘膜下造影法について。外科 診療, 16：679-684, 1975.

6）斉藤寿一他・食道癌几打ける食道粘膜下造影法 について。外科診療, $17 ： 595-600,1975$.

7) 千葉 惊他：食道癌手術適応に関する食道粘膜 下造影像の意義。日外会誌, 78：509-517, 1977.

8）芳賀甚市：食道粘膜下造影法施行切除食道の組 織学的研究. 日外会誌, $78: 547-555,1977$.

9)磯野可一他：食道癌患者の術後遠隔と左右する 因子の検討。手術, 25:1370-1377，1971.

10) 渡辺登志夫他：上中部食道癌合併症に関する検 討. 日外会誌, 74:1136-1138, - 1973.

11）遠藤光夫他：癌手術の遠隔成績, 食道. 外科診 療, 18： 863-867, 1976.

12）秋山洋他：日本における食道癌治療の現況. 内科, 43：243-249, 1979.

13）葛西森夫：食道癌の外科的治療一成績向上の道 程. 日外会誌, 81：845-853，1980.

14) 渡辺登志男他：胸部食道癌に打ける術後放射線 療法。癌の臨床, 22：199—202，1976.

15）佐藤 博他: 食道癌の遠隔成樍, 最新医学, 34: $792-796,1979$.

16）木下筫他：癌型別にみた食道癌の予後と治療 方針. 日外会誌, 81：1026-1029, 1980 .

17）山田明義他：術前 $\mathrm{X}$ 線像よりみた食道癌の治療 方針. 日外会誌, $81: 1035-1038,1980$.

18）磯野可一他：食道癌の治療方針, 病型別にみ て. 日外会誌, $81: 1054-1057,1980$. 